\title{
PENGARUH ASYMMETRIC INFORMATION TERHADAP EFEKTIFITAS MEKANISME PENGURANG MASALAH AGENSI
}

\author{
Zaenal Arifin \\ Fakultas Ekonomi Universitas Islam Indonesia
}

\begin{abstract}
This research investigates the influence of asymmetric information to the effectiveness of agency problem-reduction mechanisms in Indonesian listing companies. Using samples of manufacturing companies in Jakarta Stock Exchange from 2001-2004, this research find out that asymmetric do have influence the effectiveness of dividend mechanism in reducing agency problem. The dividend mechanism effectives in reducing agency problem only if the level of asymmetric information is high. This research also find out that the debt mechanism and the independent board of direction mechanism do not effective in reducing agency problem whether the level of asymmetric information high or low.
\end{abstract}

Keywords: asymmetric information, agency problem, dividend, debt, and independent board of director

\section{PENDAHULUAN}

Masalah agensi antara manajer dan pemegang saham pada banyak perusahaan di Amerika Serikat telah diidentifikasi oleh Barle dan Means (1932) sebagai akibat adanya perbedaan antara orang yang mengelola (manajer) dan yang memiliki perusahaan (pemegang saham). Manajer hanya memiliki porsi kepemilikan yang sangat kecil sehingga punya kecenderungan mengambil keputusan yang kurang sejalan dengan kepentingan pemegang saham dan pada saat yang sama masing-masing pemegang saham juga hanya memiliki porsi kepemilikan yang kecil sehingga mereka enggan melakukan pengawasan secara serius terhadap perilaku manajer. Pola kepemilikan perusahaan di Amerika Serikat memang cenderung menyebar (dispersed) sehingga dua kondisi di atas muncul.

Di Indonesia, masalah agensi juga muncul pada perusahaan-perusahaan yang sudah go public meskipun akar permasalahannya tidak sama dengan masalah agensi di Amerika Serikat. Sebagian besar perusahaan go public di Indonesia masih dimiliki secara mayoritas/dominan oleh keluarga pendiri perusahaan dan keluarga pendiri ini terlibat dalam manajerial perusahaan. Kondisi ini memunculkan masalah agensi antara pemegang saham mayoritas, yang juga sebagai manajer perusahaan, dengan pemegang saham minoritas. Kurniawan dan Indriantoro (2000), misalnya, menengarahi bahwa struktur kepemilikan yang masih didominasi keluarga menyebabkan perlindungan terhadap investor kecil masih lemah.

Arifin (2003) melakukan pengujian efektifitas beberapa mekanisme untuk mengurangi masalah agensi dalam konteks konflik agensi di Indonesia dan menemukan bahwa hanya mekanisme pembayaran dividen yang tinggi yang efektif untuk mengurangi masalah agensi di Indonesia. Mekanisme porsi hutang tinggi dan kontrol oleh pemegang saham mayoritas/dominan tidak efektif untuk mengurangi masalah agensi di Indonesia. Mengapa mekanisme pengurang agensi yang terbukti efektif untuk mengurangi masalah agensi di Amerika 
Serikat, seperti peningkatan porsi hutang, tidak efektif jika diaplikasikan di Indonesia. Salah satu kemungkinan jawabannya adalah karena adanya perbedaan tingkat asymmetric information antara perusahaan-perusahaan di Amerika Serikat dan perusahaanperusahaan go public di Indonesia.

Asymmetric information adalah suatu kondisi dimana ada satu pihak memiliki informasi yang lebih baik dari pada pihak yang lain. Dalam konteks perusahaan, manajer memiliki informasi yang lebih baik tentang kondisi perusahaan dibandingkan dengan investor yang tidak terlibat dalam manajemen. Asymmetric information akan memunculkan masalah salah pilih (adverse selection) karena investor tidak mengetahui dengan pasti mana perusahaan baik dan mana yang buruk. Asymmetric information juga akan memunculkan perilaku moral hazard yaitu tindakantindakan manajer yang bertentangan dengan upaya meningkatkan nilai perusahaan. Dari uraian di atas nampak bahwa masalah agensi bisa muncul sebagai dampak buruk asymmetric information sehingga jika dampak buruk tersebut dikurangi maka masalah agensi juga mestinya akan berkurang.

Melihat keterkaitan antara masalah agensi dan asymmetric information seperti dikemukakan di atas, nampaknya efektifitas mekanisme pengurang agensi akan dipengaruhi oleh seberapa besar asymmetric information yang terjadi di masing-masing perusahaan. Penelitian ini berupaya untuk menguji dugaan tersebut dalam konteks permasalahan agensi di perusahaan go public di Indonesia. Penelitian ini dilakukan sebagai upaya untuk mencari mekanisme pengurang masalah agensi yang ketika tidak dikaitkan dengan asymmetric information nampaknya belum sepenuhnya efektif, seperti ditemukan oleh Arifin (2003). Pencarian mekanisme pengurang masalah agensi dalam konteks pasar modal di Indonesia sangat penting dilakukan karena jika mekanisme yang efektif tersebut ditemukan, beserta kondisi yang mensyaratkannya, maka kepercayaan investor terhadap pasar modal akan meningkat dan pada akhirnya akan berdampak positif bagi pertumbuhan perekonoman Indonesia.

Pengkaitan asymmetric information dengan masalah agensi sebetulnya bukan sesuatu yang baru karena teori agensi yang memakai pendekatan pricipal-agent (pendekatan modeling), seperti dipelopori oleh Ross (1973), menganalisis masalah agensi dengan pendekatan asymmetric information. Sesuatu yang baru yang ditawarkan dalam penelitian ini adalah bahwa asymmetric information dijadikan sebagai variabel yang diuji pengaruhnya terhadap efektifitas suatu mekanisme pengurang masalah agensi. Dengan demikian kita akan mengetahui apakah perbedaan besar kecilnya asymmetric information akan berpengaruh terhadap efektifitas suatu mekanisme pengurang masalah agensi.

\section{Masalah Agensi di Perusahaan}

Reichelstein (1992) berpendapat bahwa masalah agensi akan muncul ketika ada seorang prinsipal menyewa seorang agen untuk mengerjakan suatu pekerjaan namun si agen tidak ikut memperoleh bagian dari apa yang dia hasilkan. Sedangkan Stiglitz (1992) mengemukakan bahwa masalah antara prinsipal dan agen akan muncul ketika dalam hubungan antara prinsipal dan agen tersebut terdapat imperfect information.

Dalam konteks sebuah perusahaan, salah satu masalah agensi yang muncul adalah pada hubungan antara pemilik perusahaan dan manajer. Sebagai prinsipal, pemilik perusahaan memberi tugas kepada agen (manajer) untuk mengelola perusahaan agar nilai investasi yang ditanamkan oleh pemilik dapat tumbuh seoptimal mungkin. Namun karena manajer tidak ikut menikmati meningkatnya nilai investasi dan ditambah 
adanya imperfect information dalam hubungan pemilik dan manajer maka muncullah masalah agensi tersebut.

Masalah agensi dapat muncul dalam berbagai bentuk. Dalam konteks hubungan antara pemilik perusahaan dan manajer, masalah agensi dapat berupa penggunaan dana perusahaan untuk pembelian fasilitas manajer yang berlebihan, penahanan laba perusahaan untuk investasi yang kurang menguntungkan, dan berbagai kecurangan yang dapat mengurangi laba atau aset perusahaan seperti menjual produk perusahaan dengan harga murah ke perusahaan lain yang ternyata milik manajer. Fenomena munculnya masalah agensi inilah yang kemudian mendorong munculnya teori agensi (agency theory).

\section{PENDEKATAN PENGEMBANGAN TEORI AGENSI}

Jensen (1983) mengidentifikasi adanya dua pendekatan dalam pengembangan teori agensi yang dia namakan "positive theory of agency" dan "principalagent literatures”. Kedua pendekatan samasama menelaah kontrak diantara selfinterested individuals dan sama-sama berpostulat bahwa biaya agensi (agency cost) dapat diminimumkan dengan melalui proses kontrak serta sama-sama bertujuan mendesain kontrak yang Pareto-efficient.

Meskipun demikian, keduanya memiliki perbedaan dalam beberapa hal. Principal-agent literature pada umumnya berorientasi matematis dan non empiris serta berkonsentrasi pada efek dari preferensi dan asymmetric information. Model game theory banyak dipakai pada pendekatan ini. Sementara itu Positive agency literature pada umumnya berfokus pada uji empiris dan non-matematis serta berkonsentrasi pada efek dari teknologi sistem kontrak dan human atau physical capital yang spesifik. Model ekonometri banyak dipakai untuk menguji teori ini secara empiris.

\section{Principal-Agent Literature}

Istilah principal-agent problem dikemukakan pertama kali oleh Ross (1973). Masalah ini muncul ketika terdapat asymmetric information baik berkaitan dengan kegiatan maupun informasi yang dimiliki oleh seorang agen. Masalah yang pertama biasa dinamakan hidden action sedangkan yang kedua dinamakan hidden information. Hidden action akan memunculkan moral hazard dan hidden information akan memunculkan adverse selection.

\section{Positive Agency Literature}

Pendekatan positive agency banyak mengacu pada artikel Jensen dan Meckling (1976) tentang adanya masalah agensi dalam perusahaan yang terpisah antara kepemilikan dan manajemennya. Jensen dan Meckling (1976) mendefinisikan $\alpha$ sebagai bagian saham yang dimiliki oleh manajer. Jika $\alpha=1$ berarti perusahaan dimiliki sepenuhnya oleh manajer dan dia menanggung semua risiko jika nilai perusahaan tidak optimal sebagai akibat penggunaan sumber daya perusahaan yang tidak efektif atau bahkan mengarah pada pemborosan. Jika $\alpha<1$, berarti tindakan tidak optimal yang dilakukan manajer ditanggung tidak hanya oleh manajer tetapi juga oleh pemodal luar (outside investors). Setiap rupiah penggunaan dana akan ditanggung oleh manajer sebesar $\alpha$ dan oleh investor lain sebesar (1- $\alpha)$. Keadaaan ini membuat manajer akan cenderung meningkatkan pengeluaran 'konsumtif'-nya jika $\alpha$ semakin kecil.

Untuk mengurangi kesempatan manajer melakukan tindakan yang merugikan investor luar, Jensen dan Meckling (1976) mengidentifikasi ada dua cara yaitu investor luar melakukan pengawasan (monitoring) dan manajer sendiri melakukan pembatasan atas tindakan-tindakannya (bonding). Pada satu sisi, kedua kegiatan tersebut akan mengurangi kesempatan 
penyimpangan oleh manajer sehingga nilai perusahaan akan meningkat sedangkan pada sisi yang lain keduanya akan memunculkan biaya sehingga akan mengurangi nilai perusahaan. Jensen dan Meckling (1976) menyatakan bahwa calon investor akan mengantisipasi adanya kedua biaya tersebut ditambah dengan kerugian yang masih muncul meskipun sudah ada monitoring dan bonding, yang disebut residual loss. Antisipasi atas ketiga biaya yang didefinisikan sebagai biaya agensi ini nampak pada harga saham yang terdiskon saat perusahaan menjual sahamnya.

\section{Masalah Agensi dan Asymmetric Information}

Penelitian masalah agensi yang terkait dengan asymmetric information pada umumnya memakai pendekatan modeling. Modeling tersebut dikelompokkan dalam model untuk mengurangi hidden action dan model untuk mengurangi hidden information.

Kajian tentang masalah moral hazard dalam hidden action ini awalnya muncul dalam literatur asuransi. Dalam literatur tersebut dinyatakan bahwa ketika seseorang mengasuransikan suatu asset, maka dia tidak lagi memelihara asset tersebut dengan baik karena jika asset tersebut rusak atau hilang toh akan diganti oleh perusahaan asuransi. Biasanya tabiat buruk seperti itu sulit dibuktikan (unobservable) oleh perusahaan asuransi. Perusahaan asuransi memang dapat memasukkan klausul-lausul tentang hal-hal yang tidak boleh dilakukan oleh seseorang yang mengasuransikan terhadap asset yang mereka asuransikan namun sangat sulit membuat sebuah kontrak yang memasukkan secara rinci semua kemungkinan perilaku (buruk) ini. Oleh karena itu perlu dibuat sebuah kontrak yang dapat mengurangi moral hazard ini. Misalnya, perusahaan asuransi memberi klausul dalam kontraknya bahwa $k$ rupiah pertama dari kerusakan asset ditanggung sendiri oleh peminta asuransi. Dengan klausul seperti ini maka pengasuransi akan ikut menanggung kerugian jika asset yang diasuransikan mengalami kerusakan sehingga mereka akan menghindari dengan sengaja berperilaku buruk terhadap asset yang diasuransikan.

Dalam model dasar (awal) hidden action, seperti digambarkan oleh Grossman dan Hart (1983), hanya terdapat satu prinsipal dan satu agen. Prinsipal (pemilik) tidak dapat memonitor aktifitas agen (manajer), sehingga aktifitasnya menjadi unobservable, namun pemilik dapat mengetahui hasil dari aktifitas tersebut (misal dari laba), berarti hasilnya verifiable. Laba perusahaan tergantung pada aktifitas manajer dan faktorfaktor lain yang di luar kendali manajer. Jadi ketika kondisi perusahaan bagus, pemilik tidak dapat menafsirkan dengan pasti apakah hasil tersebut sebagai akibat manajer telah bekerja dengan baik atau hanya karena keberuntungan saja. Pada model dasar ini, kontrak yang optimal bagi prinsipal diperoleh dengan memaksimumkan laba dengan kendala "incentive compatibility" dan "individual rationality" (participation constraint).

Holmstrom dan Milgrom (1987) memodifikasi model dasar dengan mengasumsikan bahwa agen memiliki progressive information tentang kejadian suatu outcome sehingga dia dapat secara kontinyu menyesuaikan tindakannya. Model juga dikembangkan dengan mengubah asumsi oneperiod game dengan large-number-period game. serta hubungan antara seorang prinsipal dengan beberapa agen. Dengan banyak agen maka kontrak tidak lagi independen. Kompensasi terhadap seorang agen tidak lagi hanya berdasarkan kinerjanya sendiri tetapi juga perbandingannya dengan kinerja agen yang lain. Upaya pembandingan kinerja antar agen ini sering disebut tournament. Lazear dan Rosen (1981) membuat model untuk dua agen, Holmstrom (1982) 
membuat model untuk banyak agen, sedangkan Ishiguro dan Itoh (2001) membuat model dengan banyak agen disertai adanya renegosiasi.

Sementara itu hidden information dapat dicontohkan dengan permainan (game) antara seorang penjual yang mengetahui berapa biaya untuk membuat barang yang sedang dia jual, dengan pembeli yang tidak tahu ongkos produksi dari barang yang akan dibeli. Penjual yang memiliki private information akan memiliki potensi keunggulan stratejik dalam bertransaksi dengan pembeli. Dengan berperilaku seolah barangnya membutuhkan biaya yang mahal, penjual dapat membujuk pembeli untuk membayar lebih tinggi dibandingkan dengan jika pembeli mengetahui ongkos produksi yang sebenarnya. Kelebihan harga jual dari yang semestinya ini dinamakan information rent. Pembeli tentu saja menyadari kemungkinan adanya perilaku yang demikian, oleh karena itu jika dia mengajukan kontrak dengan penjual maka dia akan membuat kontrak yang dapat mengurangi information rent tersebut.

Model dasar hidden information adalah sebagai berikut. Ada dua pemain yang terlibat dalam hubungan stratejik, artinya langkah yang dimainkan seorang pemain tergantung pada langkah dari pemain yang lain. Pemain pertama memiliki private information sehingga disebut informed player sedang pemain yang lain tidak memiliki private information dan disebut uninformed player. Pemain yang mengajukan kontrak adalah prinsipal sedangkan yang menerimanya disebut agen. Jika uninformed player yang mengajukan kontrak maka modelnya disebut screening models sedangkan jika informed player yang mengajukan disebut signaling models (lihat Caillaud dan Hermalin, 2000).

Dalam konteks hubungan agensi di perusahaan, penulis merasa bahwa model untuk mengurangi hidden information lebih sering dikaji, dimana manajer/pemegang saham mayoritas merupakan informed player sementara investor luar sebagai uninformed player. Mekanisme bonding untuk mengurangi masalah agensi dengan meningkatkan dividen atau hutang seperti dikemukakan oleh Jensen dan Meckling (1976) maupun Jensen (1986), misalnya, adalah model praktis untuk model signaling. Sementara itu, strategi investor untuk memilih likuiditas saham serta ukuran perusahaan merupakan bentuk praktis dari model screening. Terkait dengan hipotesis pasar modal yang efisien, ukuran perusahaan merupakan sebuah anomali karena perusahaan yang ukurannya kecil cenderung memiliki return yang tinggi dari pada yang ukurannya besar. Salah satu penjelasan mengapa terjadi anomali ini disampaikan oleh Arbel dan Strebel (1983), yang menyatakan bahwa ada masalah neglected-firm effect pada anomali ukuran perusahaan. Perusahaan kecil cenderung tidak banyak dianalisis oleh analisis keuangan sehingga asymmetric informationnya lebih besar. Ini berarti risiko perusahaan kecil lebih besar sehingga investor meminta return yang lebih besar. Sementara itu, Amihud dan Mendelson (1991) menambahkan bahwa karena perusahaan kecil tidak banyak dianalisis maka mereka cenderung kurang likuid. Diamond dan Verrechia (1991) juga menyatakan bahwa berkurangnya asymmetric information akan meningkatkan likuiditas saham.

Dari uraian di atas nampak bahwa berkurangnya asymmetric information, baik dalam bentuk hidden action maupun hidden information, akan mengurangi masalah agensi. Asymmetric information dapat dikurangi dengan cara screening maupun signaling. Jika tingkat asymmetric information suatu perusahaan tinggi bisa jadi suatu mekanisme pengurang masalah agensi tidak akan efektif mengurangi masalah agensi namun jika tingkat asymmetric in- 
formationnya rendah maka mekanisme tersebut menjadi efektif. Oleh karena itu penulis mengajukan hipotesis bahwa:

"Tingkat asymmetric information
berpengaruh terhadap efektifitas
mekanisme pengurang masalah agensi"

\section{METODE PENELITIAN \\ Populasi dan Sampel}

Populasi penelitian ini adalah perusahaan-perusahaan yang terdaftar di Bursa Efek Jakarta (BEJ). Sampel penelitian adalah seluruh perusahaan non keuangan dari tahun 2001-2004. Pemilihan perusahaan non keuangan dilakukan karena dalam penelitian ini ada variabel debt ratio yang kurang pas jika diterapkan pada perusahaan keuangan.

\section{Definisi Operasional Variabel Penelitian}

Ada tiga variabel yang digunakan dalam penelitian ini yaitu tingkat asymmetric information, mekanisme pengurang masalah agensi, dan efektifitas mekanisme pengurang masalah agensi.

\section{Tingkat asymmetric information}

Tingkat asymmetric information dalam penelitian ini menggunakan proxy yaitu ukuran perusahaan. Pemakaian ukuran perusahaan sebagai proxy asymmetric information merujuk pada Amihud dan Mendelson (1991) dan Diamond dan Verrechia (1991). Ukuran perusahaan diukur dari nilai kapitalisasi pasar pada akhir tahun. Perusahaan yang masuk 20 besar nilai kapitalisasi pasar akan mendapat skor 1 dan mendapat skor 0 untuk yang lainnya.

\section{Mekanisme pengurang masalah agensi}

Permasalahan agensi di Indonesia lebih terlihat merupakan konflik antara pemegang saham mayoritas/manajer dan pemegang saham minoritas. Oleh karena itu mekanisme seperti meningkatkan kepemilikan manajer, pemegang saham besar, dan kepemilikan yang terkonsentrasi tidak cocok sebagai mekanisme pengurang masalah agensi dengan konteks perusahaan publik di Indonesia. Mekanisme pasar corporate control dalam bentuk akuisisi juga nampaknya tidak berjalan di Indonesia karena sangat kuatnya posisi manajer. Oleh karena itu dalam penelitian ini, mekanisme pengurang masalah agensi yang digunakan hanya tiga mekanisme yaitu: meningkatkan dividen, meningkatkan porsi hutang, dan adanya dewan komisaris independen.

\section{Efektifitas mekanisme pengurang masalah agensi}

Efektifitas mekanisme pengurang masalah agensi diukur dengan cumulative abnormal return (CAR) saham selama satu tahun dari abnormal return (AR) mingguan. AR mingguan dihitung dari return aktual mingguan dikurangi dengan return pasar mingguan. Hari yang dijadikan dasar menghitung return mingguan adalah hari Rabu. Hari Rabu dipilih karena secara umum pada hari itu perdagangan cenderung normal tidak terimbas efek pola perdagangan mingguan.

\section{Pengujian Hipotesis}

Hipotesis menyatakan bahwa tingkat asymmetric information berpengaruh terhadap efektifitas mekanisme pengurang masalah agensi. Semakin kecil tingkat asymmetric information-nya maka semakin efektif mekanismenya. Persamaan regresi yang digunakan untuk menguji hipotesis kedua adalah sebagai berikut.

$$
\begin{aligned}
& \mathrm{CAR}_{\mathrm{i}}=\alpha+\beta_{1} \mathrm{DIV}_{\mathrm{i}}+\beta_{2} \mathrm{DR}_{\mathrm{i}}+\beta_{3} \mathrm{DKI}_{\mathrm{i}}+ \\
& { }_{4} \mathrm{DIV}_{\mathrm{i}}{ }^{*} \mathrm{DAI}_{\mathrm{i}}+\beta_{5} \mathrm{DR}_{\mathrm{i}}{ }^{*} \mathrm{DAI}_{\mathrm{i}}+\beta_{6} \\
& \mathrm{DKI}_{\mathrm{i}} * \mathrm{DAI}_{\mathrm{i}}+\beta_{7} \mathrm{BETA}_{\mathrm{i}}+\varepsilon_{\mathrm{i}}
\end{aligned}
$$


$\mathrm{DIV}_{\mathrm{i}}=$ dividend payout ratio saham $\mathrm{i}$

$\mathrm{DR}_{\mathrm{i}}=$ debt ratio yaitu ratio antara total hutang dengan total asset

$\mathrm{DKI}_{\mathrm{i}}$ = variabel dummy komisaris independen, nilai 1 jika ada komisaris independen dan 0 jika tidak ada

BETA $_{i}=$ risiko sistematis saham I

$\mathrm{DAI}_{\mathrm{i}}$ = adalah dummy tingkat asymmetric information berdasarkan kapitalisasi pasar, dengan nilai 1 jika masuk 20 besar dan 0 jika tidak.

\section{HASIL PENELITIAN}

Statistik Diskriptif Variabel Penelitian

Penelitian ini menggunakan lima variabel yang gambaran umumnya nampak pada tabel 1. Dari tabel tersebut diperoleh informasi bahwa sebagai salah satu mekanisme pengurang masalah agensi yang cukup efektif, dividen yang dibayarkan perusahaan secara umum masih rendah. Ini menunjukkan bahwa banyak perusahaan yang tidak memakai mekanisme dividen sebagai pilihan untuk memberi sinyal bahwa masalah agensi di perusahaan rendah. Pada tahun 2003, pembayaran dividen memang mengalami peningkatan tetapi tahun berikutnya dividen sudah turun lagi ke posisi yang sejajar dengan besar dividen tahuntahun sebelum tahun 2003.
Sementara itu, porsi hutang perusahaan secara umum cukup tinggi terutama pada tahun 2001. Porsi hutang sebagai mekanisme pengurang masalah agensi memiliki pola kuadrat dimana peningkatan porsi hutang akan mengurangi masalah agensi ketika porsi hutang perusahaan masih rendah tetapi ketika porsi hutang sudah cukup tinggi, penambahan hutang justru akan meningkatkan masalah agensi. Disamping itu, mekanisme peningkatan hutang untuk mengurangi masalah agensi biasanya akan efektif ketika perusahaan sudah kelebihan free cash flows. Dalam konteks perusahaan go public di Indonesia, hanya sebagian kecil perusahaan yang dalam kondisi seperti itu.

Dewan komisaris independen telah ditetapkan sebagai perangkat yang wajib ada di setiap perusahaan publik sehingga ada kecenderungan jumlah perusahaan yang memiliki dewan komisaris independen semakin meningkat. Jumlah formal dari dewan komisaris pada tahun 2004 bisa jadi sudah mendekati seratus persen meskipun data pada tabel menunjukkan persentasenya masih di bawah enam puluh persen. Dalam penelitian ini, dewan komisaris independen memang didefinisikan sebagai dewan komisaris independen yang berasal dari kalangan akademisi.

Tabel 1: Statistik Diskriptif Variable Penelitian

\begin{tabular}{|c|c|c|c|c|c|c|c|c|}
\hline \multirow{2}{*}{ Variabel } & \multicolumn{2}{|c|}{2001} & \multicolumn{2}{c|}{2002} & \multicolumn{2}{c|}{2003} & \multicolumn{2}{c|}{2004} \\
\cline { 2 - 9 } & Mean & Std.Dev. & Mean & Std. Dev. & Mean & Std. Dev. & Mean & Std. Dv. \\
\hline DIV & 8.065 & 16.654 & 8.7173 & 30.728 & 12.597 & 46.825 & 8.532 & 30.283 \\
\hline DR & 0.840 & 0.6724 & 0.6469 & 0.6987 & 0.6899 & 0.6288 & 0.659 & 0.7568 \\
\hline CAR & -0.3485 & 0.7896 & -0.1646 & 1.5923 & -0.370 & 0.8991 & -0.28 & 1.4129 \\
\hline BETA & 0.6379 & 0.7223 & 0.6418 & 0.7500 & 0.5875 & 0.6024 & 0.480 & 2.3671 \\
\hline DKI & 0.3955 & 0.4900 & 0.4710 & 0.5001 & 0.4470 & 0.4981 & 0.569 & 0.4960 \\
\hline
\end{tabular}


Data cumulative abnormal return (CAR) yang dijadikan sebagai proksi tinggi rendahnya tingkat masalah agensi perusahaan menunjukkan rata-rata yang negatif. Hal ini bisa diartikan bahwa masalah agensi di perusahaan publik di Indonesia masih relatif tinggi. Sementara itu, data beta menunjukkan bahwa rata-rata beta sampel kurang dari satu. Ini menunjukkan bahwa perusahaan sampel secara umum memiliki risiko di bawah risiko pasar.

\section{Hasil Uji Hipotesis}

Uji asumsi klasik

Berdasarkan hasil uji multikolinearitas dengan matrik korelasi, nilai matrik korelasi antar variabel bebas kurang dari 0,8 artinya bahwa semua variabel bebas tidak terkena multikolinearitas sehingga tidak membahayakan interprestasi hasil analisis regresi. Masalah autokorelasi dapat di uji dengan Q-stat dan ditemukan nilai yang signifikan sehingga ada masalah autokorelasi. Untuk menyelesaikan masalah autokorelasi dengan menggunakan NeweyWest Least Square. Uji Heteroscedasticity dengan menggunakan White Heteroskedasticity dan diperoleh nilai chi square hitung (Obs*R- lebih kecil dari nilai chi square kritis pada disimpulkan tidak ada masalah Heteroscedasticity.

\section{Hasil regresi}

Uji hipotesis tentang pengaruh asymmetric information terhadap efektifitas mekanisme pengurang masalah agensi dapat dilihat dari hasil persamaan regresi pada Tabel 2 berikut ini.

Tabel 2: Model Hasil Estimasi Regresi dengan Metode Newey-West Least Squares

Dependent Variable: CAR

Method: Least Squares

Sample: 11004

Included observations: 1004

Newey-West HAC Standard Errors \& Covariance (lag truncation=6)

\begin{tabular}{crcrr}
\hline \hline Variable & Coefficient & Std. Error & t-Statistic & Prob. \\
\hline C & -0.588643 & 0.061849 & -9.517407 & 0.0000 \\
DIV & -0.001149 & 0.001486 & -0.773017 & 0.4397 \\
DR & 0.003929 & 0.052136 & 0.075357 & 0.9399 \\
DKI & 0.088737 & 0.061302 & 1.447529 & 0.1481 \\
DIV*DAI & -0.018632 & 0.006992 & -2.664829 & 0.0078 \\
DR*DAI & 0.258528 & 0.306630 & 0.843127 & 0.3994 \\
DKI*DAI & -0.068063 & 0.282451 & -0.240972 & 0.8096 \\
BETA & 0.481002 & 0.041228 & 11.66677 & 0.0000 \\
\hline \hline R-squared & 0.286872 & Mean dependent var & & -0.290663 \\
Adjusted R-squared & 0.281860 & S.D. dependent var & & 1.236219 \\
S.E. of regression & 1.047611 & Akaike info criterion & & 2.938838 \\
Sum squared resid & 1093.099 & Schwarz criterion & & 2.977975 \\
Log likelihood & -1467.297 & F statistic & & 57.23758 \\
Durbin-Watson stat & 2.606839 & Prob(F-statistic) & & 0.000000 \\
\hline \hline
\end{tabular}


Dari Tabel 2 di atas diperoleh informasi bahwa deviden mempunyai koefisien negatif dan tidak signifikan sehingga dapat disimpulkan bahwa dividen tidak berpengaruh terhadap efektifitas mekanisme pengurang masalah agensi. Hasil penelitian ini bertentangan dengan konsep Rozeff (1982) dan hasil penelitian Arifin (2003) yang menemukan bahwa peningkatan deviden akan mengurangi biaya agensi karena meningkatnya deviden akan meningkatkan kemungkinan perusahaan mengambil dana dari luar sehingga perusahaan akan sering dimonitor oleh investor.

Ketika deviden diinteraksikan dengan tingkat asymmetric information, yang diproxy dengan ukuran perusahaan, diperoleh hasil bahwa koefisiennya negatif dan signifikan. Hasil ini menunjukkan bahwa asymmetric information berperan signifikan terhadap efektifitas dividen dalam mengurangi masalah agensi. Koefisien interaksi yang negatif menunjukkan bahwa dividen hanya efektif untuk mengurangi masalah agensi ketika tingkat asymmetric information perusahaan masih tinggi. Ketika tingkat asymmetric information di perusahaan rendah, dividen tidak lagi efektif untuk mengurangi masalah agensi. Dengan kata lain, deviden tidak efektif untuk mengurangi masalah agensi pada perusahaan yang berukuran besar. Deviden akan lebih efektif sebagai pengurang masalah agensi pada perusahaan yang berukuran kecil. Hasil yang diperoleh dalam penelitian ini sesuai dengan teori Small Efect yang menyatakan bahwa bahwa ukuran perusahaan mempunyai hubungan negatif atau berlawanan dengan return, perusahaan yang berukuran kecil mempunyai return yang lebih tinggi daripada perusahaan yang berukuran besar.

Mekanisme hutang dalam peneliti an ini terbukti tidak efektif untuk mengurangi masalah agensi yang ditunjukkan oleh koefisiannya yang tidak signifikan meskipun arahnya positif. Hasil penelitian ini bertentangan dengan beberapa penelitian yang dirangkum oleh Harris dan Raviv (1991) yang menyebutkan bahwa ada hubungan positif antara hutang dengan nilai perusahaan. Namun hasil ini sesuai temuan Arifin (2003) yang juga menemukan bahwa mekanisme hutang tidak efektif untuk mengurangi masalah agensi di Indonesia.

Ketika hutang diinteraksikan dengan asymmetric information, hasilnya juga tidak berbeda, koefisien interaksinya positif dan tidak signifikan. Ini menunjukkan bahwa faktor tingkat asymmetric information tidak berperan signifikan dalam mempengaruhi efektifitas mekanisme hutang untuk mengurangi masalah agensi. Mekanisme hutang tidak efektif baik ketika tingkat asymmetric information rendah maupun tinggi. Hutang memang secara teoritis memiliki pola hubungan kuadratik dengan kinerja perusahaan. Meningkatnya hutang akan meningkatkan kinerja perusahaan ketika porsi hutang masih relatif rendah. Ketika porsi hutang sudah relatif tinggi, penambahan hutang justru akan menurunkan kinerja perusahaan. Dari data statistik diskriptif diperoleh informasi bahwa rata-rata porsi hutang perusahaan sampel adalah $64-84 \%$, sebuah porsi hutang yang relatif tinggi. Bisa jadi, hutang tidak efektif untuk mengurangi masalah agensi karena porsi hutang yang relatif tinggi dan karena investor secara umum sudah mengetahui bahwa perusahaan di Indonesia porsi hutangnya memang relatif tinggi maka informasi tentang porsi hutang tidak dikategorisasikan sebagai informasi yang asymmetric.

Mekanisme pengurang masalah agensi yang ketiga, monitoring dewan komisaris independen, juga tidak efektif terlihat dari koefisien yang tidak signifikan meskipun arahnya positif. Hasil penelitian ini sesuai dengan hasil penelitian Arifin (2003) yang menemukan bahwa pengawasan dewan komisaris terhadap manajemen pada 
umumnya tidak efektif. Koefisien interaksi antara dewan komisaris independen dan asymmetric information juga tidak signifikan dengan arah koefisien negatif. Ini berarti bahwa mekanisme monitoring dewan komisaris independen tidak efektif baik pada perusahaan dengan tingkat asymmetric information yang rendah maupun yang tinggi. Proses pemilihan dewan komisaris independen di Indonesia sebenarnya sudah cukup baik, paling tidak jika melihat adanya ketentuan tentang persetujuan pemegang saham minoritas dalam penetapan seseroang menjadi dewan komisaris independen. Tidak efektifnya monitoring dewan komisaris independen barangkali disebabkan oleh kuatnya posisi direksi dan dewan komisaris lainnya yang dipilih oleh pemegang saham mayoritas.

Dalam penelitian ini dimasukkan satu variabel kontrol yaitu beta atau risiko sistematis. Sesuai dengan teori Capital Asset Pricing Model (CAPM), dalam penelitian ini juga ditemukan bahwa beta berpengaruh positif terhadap return saham.

\section{KESIMPULAN}

Tingkat asymmetric information terbukti mempengaruhi efektifitas dividen sebagai mekanisme untuk mengurangi masalah agensi. Pada tingkat asymmetric information tinggi, dividen efektif mengurangi masalah agensi tetapi pada tingkat asymmetric information rendah mekanisme dividen tidak efektif. Temuan ini sejalan dengan fungsi dividen sebagai sinyal efektif kepada investor tentang kinerja, termasuk masalah agensi, perusahaan. Sinyal memang sangat diperlukan ketika tingkat asymmetric information di perusahaan tinggi. Dua mekanisme yang lain yaitu hutang dan dewan komisaris independen terbukti tidak efektif untuk mengurangi masalah agensi baik ketika tingkat asymmetric information tinggi mapun rendah.

Penelitian selanjutnya dapat mengelaborasi lebih lanjut peran asymmetric information dalam mempengaruhi efektifitas mekanisme pengurang masalah agensi dengan menggunakan proxy selain ukuran perusahaan sebagaimana dipakai dalam penelitian ini.

\section{DAFTAR PUSTAKA}

Amihud, Y. dan H. Mandelson. (1991). Liquidity, Asset Prices, and Financial Policy, Financial Analyst Journal, 47, pp. 56-66.

Arbel A, dan P.J. Strebel. (1983). Pay Attention to Neglected Firm, Journal of Portfolio Management, dalam Bodie, Kane, dan Marcus. (2002). Investment, Boston, USA: McGrow Hill.

Arifin, Zaenal. (2003). Masalah Agensi dan Mekanisme Kontrol pada Perusahaan dengan Struktur Kepemilikan Terkonsentrasi yang Dikontrol Keluarga, Disertasi, Universitas Indonesia, Jakarta.

Barle, A. dan G. Means. (1932). The Modern Corporation and private Property, dalam La Porta, et al (1999), Corporate Ownership Around the World, Journal of Finance, Vol.LIV, No. 2, April.

Caillaud, B dan B. E. Hermalin. (2000). Hidden-Information Agency, dalam www.haas.berkeley.edu/ $\sim$ hermalin/econ206.html

Diamond, D.W. dan R.E. Verrechia. (1991). Disclosure, Liquidity, and the Cost of Capital, Journal of Finance, 46, pp. 1325-1359. 
Grossman, J. S dan O. D. Hart. (1983). An Analysis of the Principal-Agent Problem, Econometrica, Vol. 51, No. 1, pp 7-45.

Harris, Milton dan A. Raviv. (1991). The Theory of Capital Structure, the Journal of Finance, Vol XLVI, No. 1, pp $297-355$.

Holmstrom, Bengt. (1982). Moral Hazard in Teams, the Bell Journal of Economics, No. 13, pp324- 340 .

Holmstrom, B dan P. Milgrom. (1987). dalam Guesnerie, Roger, (1992), Hidden Action, Moral hazard and Contract Theory, dalam The New Palgrave Dictionary of Money and Finance, Vol. Pp $304-309$.

Ishiguro, S dan H. Itoh. (2001). Moral Hazard and Renegotiation with Multiple Agents, Review of Economic Studies, 68, pp 1-20.

Jensen, C. Michael. (1983). Organization Theory and Methodology, Accounting Review, 58, pp319-339. . (1986). Agency Costs of Free Cash Flow, Corporate Finance, and Takeovers, American Economic Review, Vol. 76, No.2, May.

Jensen, C M dan W. H. Meckling. (1976). Theory of the Firm: Managerial Behavior, Agency Costs and Ownership Structure, Journal of Financial Economics No.3.

Kurniawan, M Dudi dan Nur Indriantoro. (2000). the Role of Disclosure in Strengthening Corporate Governance and Accountability, The Second Asian Roundtable on Corporate Governance, Hong Kong 31 May - 2 June 2000.

Lazear, E dan S. Rosen. (1992). dalam Guesnerie, Roger. (1992). Hidden Action, Moral hazard and Contract Theory, dalam The New Palgrave Dictionary of Money and Finance, Vol. Pp $304-309$.

Reichelstein, Stefan. (1992). Agency, dalam The New Palgrave Dictionary of Money and Finance, Vol. 2, pp $23-26$.

Ross, A Stephen. (1973). The Economic Theory of Agency: The Principal's Problem, American Economics Review, Vol. 63 No. 2 pp 134 - 139.

Stiglitz, E. Joseph. (1992). Principal and Agent, dalam The New Palgrave Dictionary of Money and Finance, Vol. 2, pp $185-190$. 